超高齢者の膵管内乳頭粘液性腺癌・胆管癌・胃癌の 3 重複癌の 1 例

$$
\begin{aligned}
& \multicolumn{6}{c}{\text { 福山第一病院外科, 広島市立広島市民病院外科* }} \\
& \text { 水 野 憲 治 吉 山 知 幸* 青 木 秀 樹* } \\
& \text { 塩 崎 滋 弘* 二 宫 基 樹* 高 倉 範 尚* }
\end{aligned}
$$

症例は87歳男性，以前上り膵管内乳頭粘液性腫瘍 (IPMT) を指摘され経過観察されて いたが, 黄㾝を発症し入院. 上部消化管精査で胃前庭部に早期胃癌を認めた. 膵管内乳 頭粘液性腺癌 (IPMC) の胆管, 十二指腸浸潤および胃癌の重複癌と診断し，膵頭十二指 腸切除術を行った．切除標本では IPMC，胃癌の他に上部胆管に胆管癌を認め， 3 重複 癌であった. IPMT の他藏器重複癌は比較的多いが, IPMC・胆管癌・胃癌の 3 重複癌は 稀である，予後は合併した他臓器癌により規定されることが多く, IPMT の経過観察中 は常に他臓器癌の合併を念頭に入れておく必要がある。また本症例は検索する限りでは 最高齢の膵頭十二指腸切除術施行例であったが，高粭者といえども適切な術前評価と術 後管理, 安全な手術を行えば良好な術後経過を得られると考えられた。

索引用語：脺管内乳頭粘液性腺癌, 重複癌, 超高龄者膵切除

\section{緒 言}

近年, 診断技術わよび治療法の進歩により脺管内乳 頭粘液性腫湟（以下, IPMT) の疾患概念が確立され， 症例の蓄積とともにその他藏器重複癌症例が多いこと も報告されてきだ ${ }^{1) 3\}}$. 今回われわれは, IPMT の診断 で10年間経過観察されていた, 超高齢者の膵管内乳頭 粘液性腺癌 (以下, IPMC) ・胆管癌・胃癌の 3 重複癌 に対して膵頭十二指腸切除術（以下，PD）を施行し， 良好な結果を得た。検索しえた限り，IPMC を含む同 時性 3 重複癌切除症例の報告はなく，また87歳という 超高龄者に対する PD症例もみられないことから，極 めて稀な症例と考えたので報告する。

$$
\text { 症例 }
$$

症例：87歳, 男性.

主訴：眼球結膜黄染.

既往歴：65歳時胆襄結石にて胆摘。70歳時狭心症, 以後内服加療中.

家族歴：特記すべきことなし．

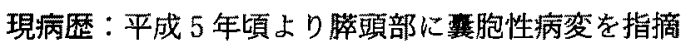
され，当院内科で経過観察されていた。平成 9 年, 経

2004 年 6 月 7 日受付 2004 年 8 月 18 日採用

〈所属施設住所〉

テ721-0973 福山市南藏王町 5-14-5
過観察中の CT で萃产胞の増大，多房化，壁在結節を 認め, IPMT の診断にて手術を勧められるも高齢を理 由に拒否, 以後も通院を行っていた。 その後も経過稪 察中の CT で IPMT は増大し, 担当医師より再三手術 を勧められていたが拒否していた，平成15年 4 月，突 然眼球結膜の黄染を認め, 精査加療目的で入院となっ t.

表 1 入院時検査所見

\begin{tabular}{lc|lr}
\hline 血算 & & 生化学検査 & \\
WBC & $4,800 / \mathrm{mm}^{3}$ & T.Bil & $3.4 \mathrm{mg} / \mathrm{dl} \uparrow$ \\
Ly & $1,344 / \mathrm{mm}^{3}$ & D.Bil & $2.6 \mathrm{mg} / \mathrm{dl} \uparrow$ \\
$\mathrm{RBC}$ & $3695 / \mathrm{mm}^{3}$ & $\mathrm{GOT}$ & $96 \mathrm{IU} / 1 \uparrow$ \\
$\mathrm{Hgb}$ & $11.7 \mathrm{~g} / \mathrm{dl}$ & $\mathrm{GPT}$ & $121 \mathrm{IU} / 1 \uparrow$ \\
$\mathrm{Hct}$ & $35.5 \%$ & $\mathrm{ALP}$ & $980 \mathrm{IU} / 1 \uparrow$ \\
$\mathrm{PIt}$ & $16.4 万 / \mathrm{mm}^{3}$ & $\mathrm{LDH}$ & $340 \mathrm{IU} / 1 \uparrow$ \\
凝固機能険查 & $\mathrm{TP}$ & $6.0 \mathrm{~g} / \mathrm{dl}$ \\
$\mathrm{PT}$ & $10.8 \mathrm{sec}$ & $\mathrm{Alb}$ & $3.2 \mathrm{~g} / \mathrm{dl}$ \\
$\mathrm{PT} \%$ & $87.7 \%$ & $\mathrm{BUN}$ & $14 \mathrm{mg} / \mathrm{dl}$ \\
$\mathrm{APTT}$ & $29.2 \mathrm{sec}$ & $\mathrm{Cr}$ & $0.8 \mathrm{mg} / \mathrm{dl}$ \\
& & $\mathrm{Na}$ & $136.6 \mathrm{mEq} / 1$ \\
& & $\mathrm{~K}$ & $4.3 \mathrm{mEq} / 1$ \\
& & $\mathrm{Cl}$ & $102.7 \mathrm{mEq} / 1$ \\
& & $\mathrm{CRP}$ & $1.29 \mathrm{mg} / \mathrm{dl}$ \\
& & $\mathrm{CEA}$ & $2.4 \mathrm{ng} / \mathrm{dl}$ \\
& & $\mathrm{CA} 19-9$ & $91.0 \mathrm{ng} / \mathrm{dl} \uparrow$ \\
\hline
\end{tabular}




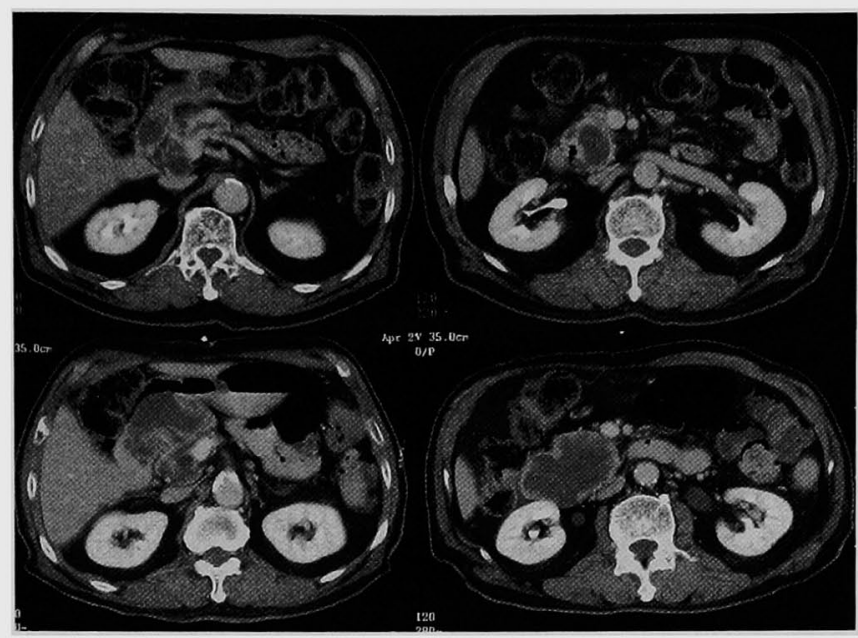

図 1 a ， b 腹部 CT (平成12年)：膵頭部から鈎部にかけての多房性 の缶胞性病変を認める. 主萃管の拡張も認める. 十二指腸に粘液の貯 留を認める。

c, d 腹部 CT (平成15年)：膵頭部から鈎部にかけての多房性 の衰胞性病変の増大を認める。 十二指腸に粘液が充満している.

$$
\begin{array}{l|l}
\mathrm{a} & \mathrm{b} \\
\hline \mathrm{c} & \mathrm{d}
\end{array}
$$

入院時現症：身長 $152 \mathrm{~cm}$ ，体重 $57 \mathrm{~kg}$. 血圧 $100 / 56$ $\mathrm{mmHg}$, 脈拍 $60 /$ 分·整, 眼球結膜に黄染を認めた。表 在リンパ節は触知せず, 腹部は平坦で軟らかく, 腫瘤 は触知しなかった.

入院時検查所見：一般血液検查で軽度の貧血を認め た. 生化学検査では総ビリルビン值は $3.4 \mathrm{mg} / \mathrm{dl}$ と上 昇し, transaminase, ALPなどの肝・胆道系酵素も上 昇していた. 腫腸マーカーでは CA19-9が $91 \mathrm{U} / \mathrm{ml}$ と高 值を示した（表 1 ).

入院後経過：入院後直ちに経皮経肝胆道ドレナージ (PTBD) を施行し減黄を図るとともに, IPMT の進 展状況, 各藏器機能の評価を行った.

腹部 $\mathbf{C T}$ : 平成 12 年の腹部 CT では脺頭部から鈎部 にかけて最大径約 $3 \mathrm{~cm}$ の多房性襄胞性病変を認め, 尾側主膵管も拡張していた(図 $1 \mathbf{a} ， \mathbf{b}$ ). 平成15年の 腹部 CT では病変はさらに増大し，十二指腸内にも著 明な粘液の貯留を認めた. 明らかなリンパ節腫大や肝 占拠性病変は認めなかった（図 $1 \mathrm{c}, \mathrm{d}$ ).

PTB 造影：胆管は総肝管レベルで閉塞し，それょり 肝側胆管は拡張していた.ガイドワイヤーは閉塞部を 容易に通過しまた同部には類円形の陰影欠損があり， いかにもムチンプラグ様の所見を認めた（図 2 a).

上部消化管造影：造影剂の通過は異常ないが，十二
指腸は粘液により充満し拡張していた（図 2 b). 上部消化管内視鏡 : Vater 乳頭開口部の開大と同部 からの粘液の流出を認め, 十二指腸内には流出した粘 液が貯留していた(図 $2 \mathrm{c}$ )。また十二指腸球部にも腫 湯穿破による粘液流出を認めた。さらに胃前庭部小彎 に浅い陥凹性病変があり (図 $2 \mathrm{~d}$ ), 同部からの生検で は group V, 高分化型腺癌と診断された.

腹部血管造影検查 : 膵周囲血管に異常は認めなかっ た.

以上より,胆管，十二指腸に浸潤を伴う IPMC と胃 癌の重複癌と診断した. 患者は高龄ではあるものの ADL は保たれており, 藏器機能にも問題なく, IPMC は浸潤癌と考えたが通常型膵癌より良好な予後が望め ること, 胃癌も早期癌であることから手術適応と考え, 平成15年 6 月手術を行った.

手術所見：腫湯は膵頭部にあり弾性硬, 膨張性発育 を呈していた，根治的切除可能と判断し，通常の胃切 除を伴う PD を施行, 再建は Child 変法 (IIA1) で行 った. なお肝側胆管断端と尾側膵管断端を迅速病理に 提出, いずれの断端も癌細胞陰性と診断された. 術中 出血量は $800 \mathrm{ml}$, 手術施行時間は 7 時間であった.

切除標本所見：胃前庭部小彎に 0 - IIC 型の病変を 認めた。 十二指腸球部には IPMC の浸潤穿破があり, 


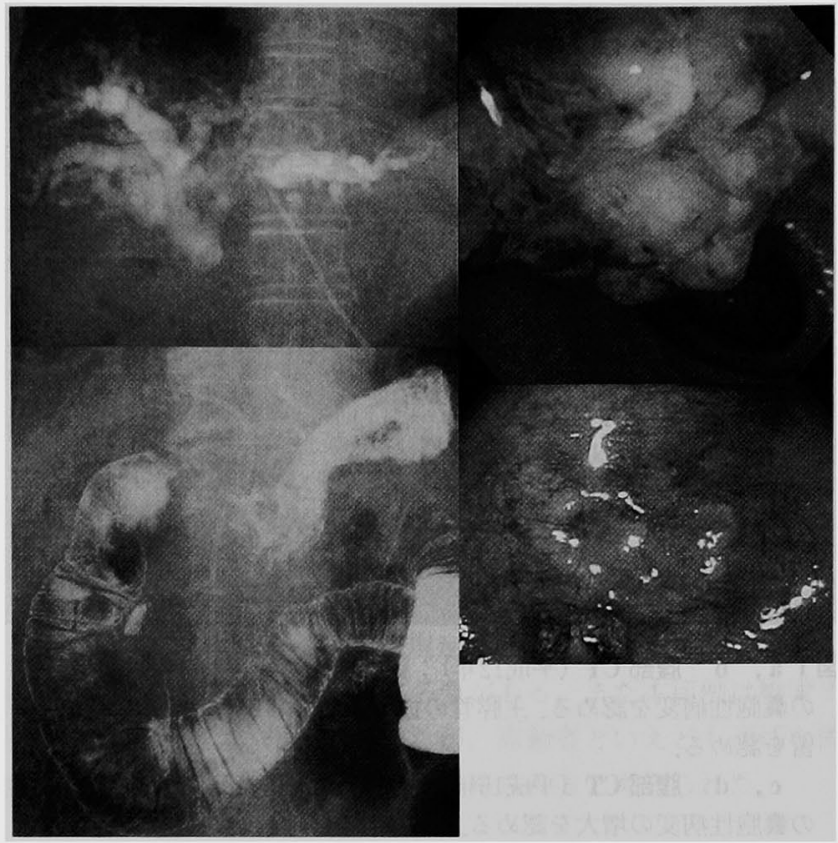

図 2 a PTB 造影：中部胆管閉塞と拡張した総胆管に透亮像を認め

る. 術前はこの透亮像をムチンプラグと判断した.

b 上部消化管造影：十二指腸の著明な拡張と透亮像を認める. ムチンプラグによるものと考えられた。

c 上部消化管内視鏡（側視）：Vater 頭開口部の開大と著明な 粘液の流出を認める。

d 上部消化管内視鏡（直視）：前庭部小彎に 0 -IIc'を認める.

$$
\begin{array}{l|l}
a & c \\
\hline b & d
\end{array}
$$

Vater 乳頭は開大していた. 胆管は IPMC の主膵管病 変に連続する形で乳頭部胆管にのみ浸潤を認めたが, 膵内胆管は IPMC 自身による直接浸潤はなく，浸潤を 受けた乳頭部胆管から離れた上部胆管に $2 \mathrm{~cm}$ 大の胆 管癌を認め，同部が胆管閉塞をきたしていた，以上か ら 3 重複癌と診断した（図 3 ).

病理組織所見：膵・胃・胆管の 3 重複癌である（図 4).膵癌は IPMC, Ph, TS4, $4.2 \times 3.1 \times 9 \mathrm{~cm}, \mathrm{INF} \alpha$, med, ly0, v0, ne0, $\operatorname{mpd}(+), \operatorname{pCH}(-), \operatorname{pDU}(+)$, $\mathrm{pS}(-), \operatorname{pRP}(-), \operatorname{pPCM}(-), \operatorname{pBCM}(-), \mathrm{pDPM}$ $(-)$, pT3pN0sM0 pStage III, 胆管癌は中分化型管状

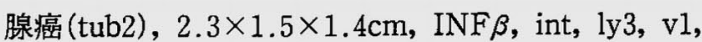
pn3, pS0(SS), pHinfo, sH0, pPanc0, pDu0, pPV0, pA0, pDM0, pHM2, pEM2, pT2pN0sH0sP0sM(-) pStage II, 胃癌は高分化型管状腺癌 (tub1), $1.8 \times 1.5$ cm, 0-IIc, ly0, v0, pPM0, pDM0, pT1(m) pN0sH0 sP0sM0pStage I A であった. 胆管断端が術中迅速診
断では陰性であったが，術後の戻し切片にて断端陽性 となり，cur Cの手術となった.

術後経過：術後 4 日目には経腸栄養を開始するとと もに積極的に離床を促した。術後 9 日目より経口摄取 開始. 合併症は一過性の夜間譫妄とカテーテル熱のみ で, 術後27日目に退院。ADL は術前と変化なく, 術後 11カ月を経過した現在，再発徴候なく健在である.

\section{考 察}

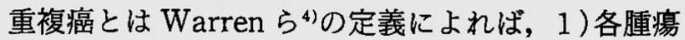
が明らかに悪性像を有し，2）互いに離れた部位に存 在し，3）一方が他方の転移でない，ことが満たされ たものをいう，本症例は胆管癌の術前診断はできてい なかったが, 最終的には膵癌, 胆管癌, 胃癌の組織所 見は異なり，先述の 3 条件を満たすことから，3 重複 癌と診断した. 以前から IPMT の他臟器重複癌の頻度 は高いことが知られているが，日本膵臓学会による多 施設全国調査を分析した鈴木ら 


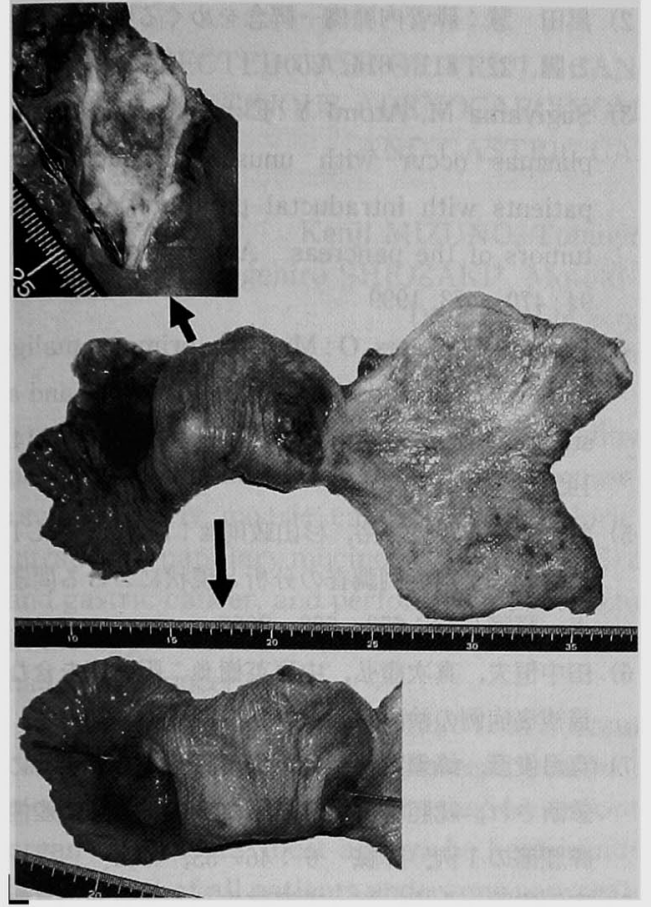

図 3 切除標本所見：a）中部胆管癌， b ) 膵頭十二 指腸切除術, c )IPMC は膵管と交通しておう, 腫 瘍の十二指腸球部に浸潤穿破した部分から Vater 乳頭開口部にゾンデを挿入できる.

$\frac{a}{b}$

IPMT 切除症例・経過観察症例のうち他藏器癌を重複 したものは267例（19.3\%）であり，内訳は胃癌86例 (32.2\%), 大腸癌57例 $(21.3 \%)$, 肝癌 20 例 $(7.5 \%)$, 肺癌16例 (6.0\%) であったと報告している.このよう にIPMT は他臟器癌を重複・合併する頻度が高く, IPMT の経過観察例では常に他臓器癌の発生を念頭 に置く必要がある，本症例は IPMC に胆管癌，胃癌を 合併した同時性 3 重複癌であるが，検索しえた限りで は同様の症例はこれまで報告されておらず，極めて稀 と考えられた．田中らは胆道癌手術78例のうち，同時 性 3 重複癌を 2 例認めたと報告し, 重複蔵器の詳細は 不明ではあるが, 胆道癌も重複頻度が高く, 他臟器癌 の存在に注意するべきであるとしている゙).

本症例は, 10 年前に膵亳胞性病変を指摘され，6 年 前に悪性を示唆する所見を認めるも，高齢を理由に検 查や手術を拒否され，経過観察をしてきた症例である。 このように, 長期にわたって経過観察後, 切除を行っ た症例は真弓ら ${ }^{7)}$, 家田ら ${ }^{8)}$, 上田ら ${ }^{9)}$ が各々報告してい

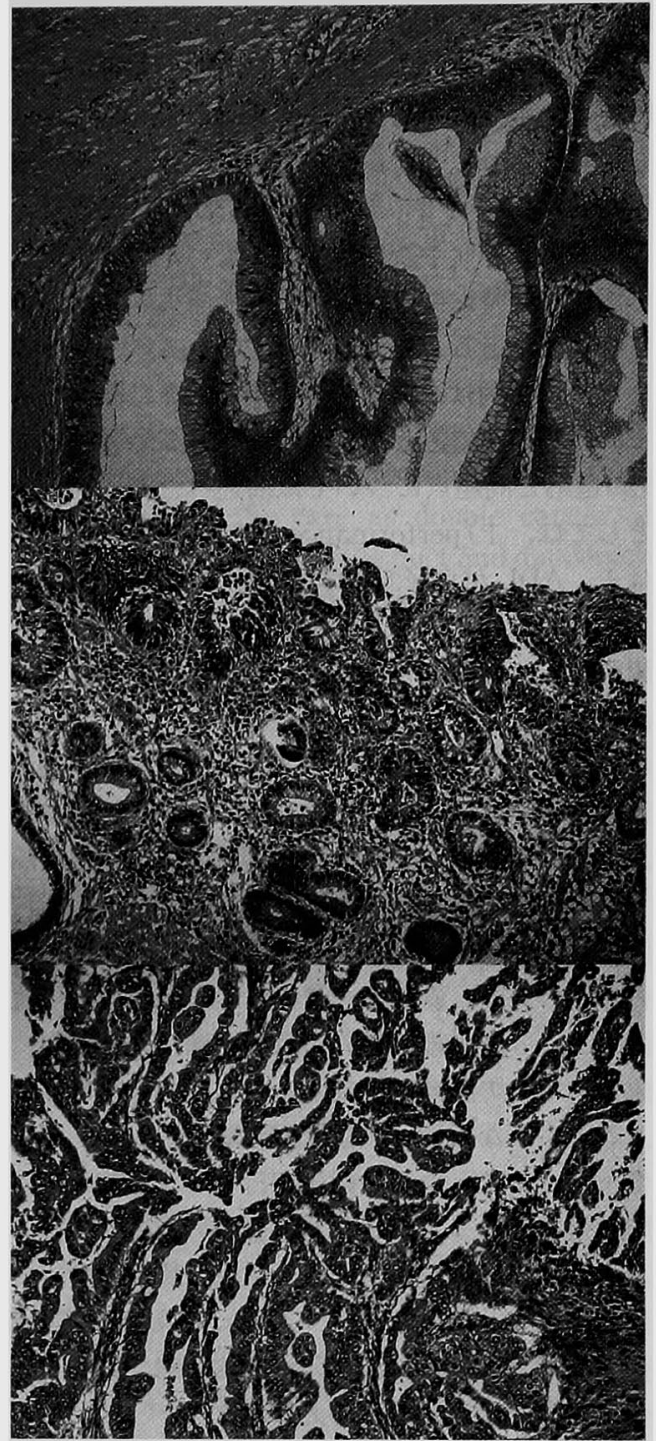

図 4 a IPMC 病理組織 $(\mathrm{HE}$ 染色 $\times 200)$ : 膵管内の 粘液産生性の異型細胞が乳頭状に增殖している.

b 胃癌病理組織 $(\mathrm{HE}$ 染色 $\times 200) ：$ tub1 m ly0 v0.

c 胆管癌病理組織 $(H E$ 染色 $\times 200):$ tub2 Int $\inf \beta$ ly 3 vis $(-)$ ss.

$$
\frac{a}{b}
$$

るが，これらの経過観察期間から, IPMT の増殖・浸 潤・進展速度は極めて緩徐であると考えられる.IPMT の予後は, Kimura ら ${ }^{100}$ の本邦および欧米報告, 計 259 例の検討では, 切除例の 5 年生存率は $82.6 \%$ であり, 脺外浸潤，他臟器穿破例では $28 \%$ と低下するものの， 


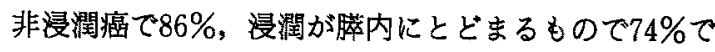
あると報告している，従って，IPMT の他藏器重複癌 症例では, 予後規定因子が重複した他臓器癌によるこ とも比較的多いと考えられる。本症例は十二指腸浸潤 を伴う IPMCであり，また肝側胆管断端に癌遺残があ ることから良好な予後は期待できないが，今後も引き 続術後の異時性重複癌の発生も考慮にいれ，経過観 察する必要があると考える310) 13).

また，本症例は過去の報告を検索しえた限り最高龄 のPD施行症例である．われわれは超高齢者に対する PDの適応と問題点について以前述べたが化, 手術適 応としては，1) performance status \& Grade 0 もし くは $1, \mathrm{ADL}$ が良好で身体的自立ができていること. 2) 肺・心・肝・腎などの重要䁍器に大きな障害がな く耐術可能であること．3）cur B 以上の手術が可能 であること４4）家族の状況が術後の患者の予想され うる状況を理解し受容可能であることである.ただし 浸潤性膵管癌は今なお手術成續が不良であることか ら, 超高齢者に対しては積極的切除の適応からは除外 している。また超高齢者のPD施行にあたっては，1） 上腸間膜動脈周囲リンパ節や傍大動脈リンパ節の郭清 岋行わない，2）剥離面を最小にし，出血量を可及的 に減らす．3）手術時間の可及的短縮．4) 術中に経 腸栄責のための腸瘦を作成する，以上のようにしてい る.このような手術・周術期管理を行うことで, $\mathrm{ADL}$ を低下させることなく, 術後27日という比較的早期の 退院が可能となった。 IPMT 法堙場の進展が緩徐, か つ高齢者に発症しやすいため5), 今後, 超高齢者での手 術例も増えると予想される.しかし, 適切な術前評価・ 手術手技·術後管理を行えば, 根治的切除である PDも 安全に施行できるものと考えられる。

\section{結語}

今回われわれは, 超高齢者の亟めて稀な同時性 3 重 複癌 (IPMC, 胆管癌, 胃癌) を経験し, PD を施行し た. IPMT は他臟器癌合併頻度が高く, 常に他藏器癌 の併存あるいは発生を念頭に入れておかなければなら ない。また超高路者であっても適切な術前評価・手術 手技・術後管理を行えば，PDも安全に施行できると考 えられた。

\section{文献}

1）日本膵臓学会編：膵癌取扱い規約，第 5 版，金原 出版, 東京, 2002

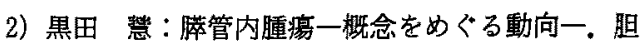
と膵 $22: 811-814,2001$

3) Sugiyama $M$, Atomi $Y:$ Extrapancreatic neoplasmas occur with unusual frequency in patients with intraductal papillary mucinous tumors of the pancreas. Am J Gastroenterol $94: 470-473,1999$

4) Warren $S$, Gates $O$ : Multiple primary malig. nant tumors. A survey of the literature and a stastical study. Am J Cancer $16: 1358-1414$, 1932

5）鉿木 裕, 跡見 裕, 杉山政則地：IPMT, MCT における全国症例調查の分析と現状における問題 点. 膵葴 $18: 653-663,2003$

6）田中恒夫, 真次康弘, 中原英樹他：胆道癌を含む 重複癌症例の検討。胆道 $18: 29-34,2004$

7) 真弓拨彦, 蜂須賀喜多男, 山口晃弘他：10年前に 䛦断され，総胆管・十二指腸に穿破した粘液産性 脺腫瘍の I 例。膵䑏 $6: 46-53,1991$

8）家田秀明, 小川 裕, 吉岡宣夫他：9 年間の長期 にわたり経過観察しえた分枝型膵管内腫婸の 1 例. 膵蔵 $10: 31-37,1995$

9）上田順彦，根塚秀昭，山本精一他：膵赛胞として 5 年間経過を観察した微小浸潤を伴った膵管内乳 頭腺癌の 1 例. 胆と脺 $21 ： 933-938 ， 2000$

10) Kimura $W$, Sasahira $N$, Yoshikawa $T$, et al: Duct-ecatatic type of mucin producing tumors of the pancreas: New concept of pancreatic neoplasia. Hepato-Gastroenterology $43: 692-$ 709, 1996

11）福嶋敬宜，向井 清：傽管内乳頭腺癌の膵管外進 展機序一他藏器穿破機序も含めて一, 胆と腈 $20: 17-20,1999$

12）川原田嘉文, 岩田 真, 横井 一：浸潤性膵管内 乳頭腺憈の予後一他藏器穿破例一. 胆と脺 20 ： 51-56, 1999

13）永川宅和, 亘原正都 : 胆道癌 Stage 分類からみた 治療評価. 肝 - 胆 - 萃 $48: 89-96,2004$

14）高倉範尚, 志摩泰生, 木村臣一他：80歳以上の高 齢者に対寸る膵頭十二指腸切除術一適応と問題点 一. 日臨外会誌 60 (增刊号) : 223, 1999 


\title{
A RESECTED CASE OF TRIPLE CANCER INVOLVING INTRADUCTAL PAPILLARY MUCINOUS ADENOCARCINOMA OF PANCREAS, BILE DUCT CANCER, AND GASTRIC CANCER IN AN AGED PERSON
}

\author{
Kenji MIZUNO, Tomoyuki YOSHIYAMA*, Hideki AOKI*, \\ Shigehiro SHIOZAKI*, Motoki NINOMIYA* and Norihisa TAKAKURA* \\ Department of Surgery, Fukuyama Daiichi Hospital \\ *Department of Surgery, Hiroshima City Hospital
}

An 87-year-old man who had been followed for intraductal papillary mucinous tumor (IPMT) of pancreas was admitted to the hospital because of development of jaundice. Upper gastrointestinal series revealed early gastric cancer at the pyloric antrum. We diagnosed the case as double cancer of intraductal papillary mucinous cancer (IPMC) of pancrease with invasion into the bile duct and duodenum and gastric cancer, and performed a pancreatoduodenectomy. On the resected material bile duct cancer in the upper bile duct was identified besides IPMC of pancreas and gastric cancer. Namely the patient had triple cancer.

It is relatively common that IPMT occurs simultaneously with cancer of other organ, but triple cancer comprising IPMC of pancreas, bile duct cancer and gastric cancer is rare. The prognosis of such multiple cancers is often determined by cancers of other organs, so that a possible association with other organ malignancy must always be kept in mind in following patients with IPMT. Further this patient is the oldest of all patients undergone pancreatoduodenectomy as far as we could review. It suggests that even aged patients are able o have uneventful postoperative course, if appropriate preoperative assessment, postoperative management, and safe operation are made. 